\title{
O formalismo-valorativo no confronto com o formalismo excessivo
}

\author{
Carlos Alberto Alvaro de Oliveira* *
}

\section{INTRODUÇÃO}

Em outra sede, procurei analisar a antinomia existente entre formalismo e justiça, buscando dar solução a esse aflitivo problema que assola o direito processual, preocupado com a adequada realização do direito material e dos valores constitucionais.' ${ }^{2}$ No presente ensaio não só tento refinar aquelas idéias, dando-Ihes maior objetividade e praticidade, como também desenvolver mais amplamente os conceitos ali lançados.

Começo conceituando o que seja formalismo, para extremá-lo da concepção nova por mim elaborada de formalismo-valorativo. Estabeleço depois os principais valores e princípios com que deve trabalhar o processo. Final- mente, à luz dessas premissas proponho soluções para combater o excesso de formalismo. Essa tarefa parece-me da maior importância, no atual ambiente em que se processa a administração da justiça no Brasil, em que muitas vezes, para facilitar o seu trabalho, o órgão judicial adota uma rigidez excessiva, não condizente com o estágio atual do nosso desenvolvimento, ou então a parte insiste em levar às últimas conseqüencias as exigências formais do processo.

\section{DEFINIÇÃO DO FORMALISMO}

O formalismo, ou forma em sentido amplo, não se confunde com a forma do ato processual individualmente con-

\footnotetext{
* Professor titular de Direito Processual Civil da Faculdade de Direito da Universidade Federal do Rio Grande do Sul; doutor em Direito pela USP, desembargador aposentado do TJRS, advogado em Porto Alegre e Brasília.

1 OLIVEIRA, Carlos Alberto Alvaro de. Do formalismo no processo civil. 2. ed. São Paulo: Saraiva, 2003, passim.
} 
siderado. Diz respeito à totalidade formal do processo, compreendendo não só a forma, ou as formalidades, mas especialmente a delimitação dos poderes, faculdades e deveres dos sujeitos processuais, coordenação de sua atividade, ordenação do procedimento e organização do processo, com vistas a que sejam atingidas suas finalidades primordiais. A forma em sentido amplo investe-se, assim, da tarefa de indicar as fronteiras para o começo e o fim do processo, circunscrever o material a ser formado, e estabelecer dentro de quais limites devem cooperar e agir as pessoas atuantes no processo para o seu desenvolvimento. O formalismo processual contém, portanto, a própria idéia do processo como organização da desordem, emprestando previsibilidade a todo o procedimento. ${ }^{2}$ Se o processo não obedecesse a uma ordem determinada, cada ato devendo ser praticado a seu devido tempo e lugar, fácil entender que o litígio desembocaria numa disputa desordenada, sem limites ou garantias para as partes, prevalecendo ou podendo prevalecer a arbitrariedade e a parcialidade do órgão judicial ou a chicana do adversário. ${ }^{3}$ Não se trata, porém, apenas de ordenar, mas também de disciplinar o poder do juiz e, nessa perspectiva, o formalismo processual atua como garantia de liberdade contra o arbítrio dos órgãos que exercem o poder do Estado. ${ }^{4}$ Pondere-se, dentro dessa linha, que a realização do procedimento deixada ao simples querer do juiz, de acordo com as necessidades do caso concreto, acarretaria a possibilidade de desequilíbrio entre o poder judicial e o direito das partes. E dessa maneira poderia fazer até periclitar a igual realização do direito material, na medida em que a discrição do órgão judicial, quanto ao procedimento e o exercício da atividade jurisdicional, implicaria o risco de conduzir a decisões diversas sobre a

2 Destaca DINAMARCO, Cândido R. A instrumentalidade do processo. 2. ed. rev. e atual. São Paulo: Revista dos Tribunais, 1990, n. 28, p. 252, que "ao reduzir as opções de comportamento de cada um dos sujeitos do processo, o direito evita a situação de extrema complexidade que geraria incertezas e faria perigar a própria integridade dos direitos e obrigações da ordem substancial e a fidelidade do processo aos seus objetivos".

$3 \mathrm{O}$ fenômeno foi assinalado corretamente por JHERING, Rudolf von Geist des römischen Rechts auf den verschiedenen Stufen seiner Entwicklung. Aalen: Scientia Verlag, 1968, v. $3, \S 50$, p. 25-26 (reprodução inalterada da 5. ed. de Leipzig de 1906).

4 JHERING, Geist..., v.2, t. $2, \S 45$, p. 470-471, no exaustivo estudo histórico que empreendeu sobre o formalismo em geral, depois de ressaltar a particular relação entre forma e liberdade, duas idéias fundamentais do direito romano, e de destacar que o mais completo desenvolvimento da era da liberdade marca também o reinado mais tirânico do rigor formal, cedendo sua severidade somente quando a liberdade passou a desaparecer, conclui essas considerações com a frase célebre: "A forma é a inimiga jurada do arbítrio e irmã gêmea da liberdade" ("Die Form ist die geschworene Feindin des Wilkür, die Zwillingsschwester der Freiheit"), que ainda hoje merece atenção. 
mesma espécie de situação fática material, impedindo uma uniforme realização do direito. ${ }^{5}$ Não bastasse isso, se constrangido o órgão judicial de cada processo a elaborar para o caso concreto, com grande desperdício de tempo, os próprios princípios com a finalidade de dar forma ao procedimento adequado, permaneceria inutilizável o tesouro da experiência colhida da história do direito processual. ${ }^{6}$

O formalismo processual controla, por outro lado, os eventuais excessos de uma parte em face da outra, atuando por conseguinte como poderoso fator de igualação (pelo menos formal) dos contendores entre si. ${ }^{7} \mathrm{O}$ fenômeno oferece duas facetas: no plano normativo, impõe uma equilibrada distribuição de poderes entre as partes, sob pena de tornar-se o contraditório uma sombra vã; no plano do fato, ou seja do desenvolvimento concreto do procedimento, reclama o exercício de poderes pelo sujeito, de modo a que sempre fique garantido o exercício dos poderes do outro. ${ }^{8} \mathrm{O}$ justo equilíbrio presta-se, portanto, para atribuir às partes, na mesma medida, poderes, faculdades e deveres, de modo a que não seja idealmente diversa sua possível influência no desenvolvimento do procedimento e na atividade cognitiva do juiz, faceta assaz importante da própria garantia funda-

5 Assim, BAUR, F. Funktionswandel des zivilprozesses? In: BEITRÄGE zur gerichtsverfassung und zum zivilprozessrecht. Tübingen: J.C.B. Mohr, 1983, p.177-193, esp. p. 186-187. SCHMIDT, Eike Der zweck des zivilprozess und seine ökonomie. Tübingen: Athenäum, 1973, n. 3.2, p. 40-41, defende também o positivismo do direito procedimental, argumentando que o controle do resultado material obtido no processo só é assegurado quando as formas previstas de investigação fática e jurídica tenham sido totalmente observadas, com o que se garante também a legítima influência das partes no curso concreto do procedimento, pois é objeto do processo o seu conflito social e não qualquer outro. Aduz, ainda, ser do interesse de todos os participantes - tanto das partes quanto das instâncias de controle - que se possa confiar na observância de um caminho procedimental formalizado, pois o processo declarativo faltaria a sua finalidade sem a correta investigação da base concreta do conflito.

6 Segundo a justa observação de SCHIMA, Hans. Compiti e limiti di una teoria generale dei procedimenti. Rivista Trimestrale di Diritto e Procedura Civile, Milano, n. 7, p. 757-772, 1953, esp. n. 3, p. 761-762. Na mesma passagem, o conhecido professor da Universidade de Viena ressalta também que se o processo fosse organizado discricionariamente pelo juiz não se poderia prever o seu curso, faltando as garantias necessárias para seu desenvolvimento.

7 Acertadamente, afirma GAUL, Hans F. Zur Frage nach dem Zweck des Zivilprozesses. Archiv für die Civilistische Praxis, n. 168, p. 27-62, 1968, esp. p. 38-39, reportando-se a Bötticher, que é sempre indispensável um determinado formalismo judicial, pois "só assim é garantida a igual atividade das partes, isto é, o princípio da paridade de armas no processo concreto, como também uma determinada previsibilidade de todo procedimento". 8 Cf. FABRI, Giovanni. Potere del giudice (dir. proc. civ.). In: ENCICLOPEDIA del diritto. Milano: Giffrè, 1985, v. 34, p. 721-744, esp. n. 2, p. 723. 
mental do contraditório. Embora se cuide aqui de um postulado lógico, não se pode deixar de reconhecer que sua realização é garantida apenas pela forma em sentido amplo. ${ }^{9}$ Aspecto significativo do processo concerne à determinação dos fatos, pois, em princípio, não é possível fixar o direito adequado à solução da controvérsia sem investigar o suporte fático descrito pelo texto normativo, dito como incidente e do qual se reclama aplicação. ${ }^{10}$ Daí também a influência do formalismo na formação e valorização do material fático de importância para a decisão da causa.

\section{A NOVA CONCEPÇÃO DO FORMALISMO-VALORATIVO}

Das considerações até agora realizadas, verifica-se que o formalismo, ao contrário do que geralmente se pensa, constitui o elemento fundador tanto da efetividade quanto da segurança do processo. A efetividade decorre, nesse contexto, do seu poder organizador e ordenador (a desordem, o caos, a confusão decididamente não colaboram para um processo ágil e eficaz), a segurança decorre do seu poder disciplinador. Sucede, apenas, que ao longo do tempo o termo sofreu desgaste e passou a simbolizar apenas o formalismo excessivo, de caráter essencialmente negativo.

De notar, ainda, que os verbos ordenar, organizar e disciplinar são desprovidos de sentido se não direcionados a uma determinada finalidade. $\mathrm{O}$ formalismo, assim como o processo, é sempre polarizado pelo fim.

Desses aspectos fundamentais do fenômeno do formalismo é indissociável outra reflexão: o processo não se encontra in res natura, é produto do homem e, assim, inevitavelmente, da sua cultura. Ora, falar em cultura é falar em valores, pois estes não caem do céu, nem são a-históricos, visto que constituem frutos da experiência, da própria cultura humana, em suma. Segundo a original elaboração de Rickert, além de constituir elemento de ligação entre os mundos do ser e do dever-ser, a cultura "é o complexo rico e multifacetado reino da criação humana, de tudo aquilo que o homem consegue arrancar à fria seriação do natural e do mecânico, animando as coisas com um sentido e um significado, e realizando através da História a missão de dar valor aos fatos e de humanizar, por assim dizer, a Natureza"." Por isso

9 Como observa TROLLER, Alois. Von den Grundlagen des zivilprozessualen Formalismus. Basel: Helbing, Lichtenhahn, 1945, § 2, 4, p. 17.

10 Aspecto ressaltado já em 1914 por CALAMANDREI, Piero. La genesi logica della sentenza civile, In: Opere giuridiche. Napoli: Morano, 1965, v. 1, p. 11-54, esp. p. 25: “[...] non si puó tuttavia negare che nella gran maggioranza dei casi la bontà della sentenza sta in diretta relazione col grado di acuratezza posto dal giudice nell' indagare esattamente il rapporto di fatto".

11 RICKERT, Ciencia cultural y ciencia natural, p. 23 et seq. apud REALE, Miguel. Fundamentos do direito. 3. ed. São Paulo: Revista dos Tribunais, 1998, p. 179. 
mesmo mostra-se totalmente inadequado conceber o processo, apesar do seu caráter formal, como mero ordenamento de atividades dotado de cunho exclusivamente técnico, integrado por regras externas, estabelecidas pelo legislador de modo totalmente arbitrário. ${ }^{2}$ A estrutura mesma que the é inerente depende dos valores adotados e, então, não se trata de simples adaptação técnica do instrumento processual a um objetivo determinado, mas especialmente de uma escolha de natureza política, escolha essa ligada às formas e ao objetivo da própria administração judicial.

Desse modo, a questão axiológica termina por se precipitar no ordenamento de cada sistema e na própria configuração interna do processo, pela indubitável natureza de fenômeno cultural deste e do próprio direito, fazendo com que aí interfira o conjunto de modos de vida criados, apreendidos e transmitidos de geração em geração, entre os membros de uma determinada sociedade. Por essa razão, ressalta-se entre nós, com grande propriedade, que no processo "se fazem sentir a vontade e o pensamento do grupo, expressos em hábitos, costumes, símbolos, fórmulas ricas de sentido, métodos e normas de comportamento". Esses fatores determinam com que nele se reflita "toda uma cultura, considerada como o conjunto de vivências de ordem espiritual e material, que singularizam determinada época de uma sociedade". ${ }^{13}$ Por conseqüência, mesmo as normas aparente-

12 Friedrich Stein, no prefácio aposto à $1^{\mathrm{a}}$ ed. de seus Grundriss des Zivilprozessrechts und des Konkursrechts, reproduzido na 3a. ed., atualizada por Josef Juncker, com necrológio de Richard Schmidt, Tübingen, J.C.B Mohr (Paul Siebeck), 1928, p. XIV, chegou a pregar que "der Prozess ist für mich das 'technische Recht' in seiner allerschärfsten Ausprägung, von wechselden Zweckmässigkeiten beherrscht, der Ewigkeistwerte bar" (o processo é para mim 'direito técnico' em sua mais aguda manifestação, dominado por conveniências cambiáveis, sem valor permanente). A bem da verdade, contudo, não se pode deixar de registrar que o próprio Stein em 1893 reconhecera, de modo significativo, que "o processo nunca pode estar à frente da sabedoria de seu tempo e de seu povo" ("Auch der Prozess kann nirgends der Erkenntniss seiner Zeit und seines Volkes voraus sein"). (STEIN, Friedrich. das private wissen des Richters: Untersuchungen zum Beweisrecht heider Prozesse, 2. Aalen: Scientia, 1987, §2, p. 31).

13 LACERDA, Galeno. Processo e cultura. Revista de Direito Processual Civil, São Paulo, n. 3, p. 74-86, 1962, esp. p. 75, que pondera ainda: "Costumes religiosos, princípios éticos, hábitos sociais e políticos, grau de evolução científica, expressão do indivíduo na comunidade, tudo isto, enfim, que define a cultura e a civilização de um povo, há de retratar-se no processo, em formas, ritos e juízos correspondentes. Ele, na verdade, espelha uma cultura, serve de indice de uma civilização". Também DINAMARCO, $A$ instrumentalidade..., cit., p. 217, aduz ser indispensável, na determinação dos fins do Estado e (conseqüentemente) dos escopos da jurisdição, ter em vista as necessidades e aspirações de seu povo, no tempo presente, entrando aí o elemento cultural, a determinar concretamente os conceitos de bem comum, de Justiça e, particularmente, de Justiça social. 
mente reguladoras do modo de ser do procedimento não resultam apenas de considerações de ordem prática, constituindo no fundamental expressão das concepções sociais, éticas, econômicas, políticas, ideológicas e jurídicas, subjacentes a determinada sociedade e a ela características, e inclusive de utopias. Ademais, o seu emprego pode consistir em estratégias de poder, direcionadas para tal ou qual finalidade governamental. ${ }^{14}$ Daí a idéia, substancialmente correta, de que o direito processual é o direito constitucional aplicado, ${ }^{15}$ a significar essencialmente que o processo não se esgota dentro dos quadros de uma mera realização do direito material, constituindo, sim, mais amplamente, a ferramenta de natureza pública indispensável para a realização de justiça e pacificação social.
Além disso, não só as formas externas, por meio das quais se desenvolve a administração da justiça, mas também os métodos lógicos empregados para o julgamento exibem valor contingente, a ser estremado consoante as circunstâncias de dado momento histórico, influenciando inclusive na conformação do processo. ${ }^{16}$

Não se pode negar, por outro lado, o aproveitamento de técnicas e soluções para problemas comuns, não obstante a diversidade de valores entre os povos. Isso se dá principalmente em virtude de uma base comum a todos os homens e o conseqüente estabelecimento de uma ponte entre eles, com intercomunicação de culturas no tempo e no espaço. ${ }^{17}$ Intercomunicação esta que tende a se tornar cada vez mais hiperativa, não só pela facilidade de

14 Acerca das estratégias governamentais de exercício do poder estatal e sua relação com o processo, a reflexão importante de SILVA, Carlos Augusto. O processo civil como estratégia de poder: reflexo da judicialização da política no Brasil. Rio de Janeiro: Renovar, 2004, passim.

15 Cf. GAUL, Zur Frage..., p. 32. Idéia semelhante, aliás, era defendida já por POLLAK, Rudolf. Sistem des Österreichischen Zivilprozessrechtes. 2. ed. Wien: Manz, 1932, p. III, para quem o direito processual civil constitui, em muitos aspectos, uma das mais importantes partes do direito constitucional. A respeito, ainda, OLIVEIRA, Carlos Alberto Alvaro de. O processo civil na perspectiva dos direitos fundamentais. Revista Forense, Rio de Janeiro, n. 372, p. 77-86, mar./abr. 2004.

16 Como ressalta com acerto CALAMANDREI, Piero. Istituzioni di diritto processuale civile. In: OPERE giuridiche. Napoli: Morano, 1970, v. $4, \S 8^{\circ}$, p. 34. Sobre a influência da lógica na conformação do processo, o ensaio seminal de PICARD, Nicola. Processo civile (dir. moderno). In: ENCICLOPEDIA del diritto. Milano: Giuffrè, 1987, v. 36, p. 110-117.

17 Assim filosofa, argutamente, BERLIN, Isaiah. A busca do ideal. In: HARDY, Henry (Org.) Limites da utopia: capítulos da história das idéias. Tradução Valter Lellis Siqueira. São Paulo: Companhia das Letras, 1991, p. 21 , ponderando ainda que os fins e os princípios morais são variados, mas não infinitamente variados: eles devem situar-se nos limites do horizonte humano. 
comunicação característica da fase atual da história da humanidade mas pela própria globalização da economia, propulsionadora da adoção de um modelo técnico único. O formalismo, contudo, exatamente porque fenômeno cultural, informado por valores, não se confunde com a técnica, que é neutra a respeito da questão axiológica. ${ }^{18}$

Postas essas premissas, é preciso repensar o problema como um todo, verificar as vertentes políticas, culturais e axiológicas dos fatores condicionantes e determinantes da estruturação e organização do processo, estabelecer enfim os fundamentos do formalismo-valorativo. E isso porque seu poder ordenador, organizador e coordenador não é oco, vazio ou cego, pois não há formalismo por formalismo. Só é lícito pensar no conceito na medida em que se prestar para a organização de um processo justo e servir para alcançar as finalidades últimas do processo em tempo razoável e, principalmente, colaborar para a justiça material da decisão.

Ao meditar-se nos fatores externos do formalismo, o pensamento desde logo tende, em formulação esquemática inicial bastante ampla, a fixar-se nos fins do processo, e a noção de fim entre- laça-se, necessariamente, com o valor ou valores a serem idealmente atingidos por meio do processo. Impõe-se, portanto, a análise dos valores mais importantes para o processo: por um lado, a realização de justiça material e a paz social, por outro, a efetividade, a segurança e a organização interna justa do próprio processo (fair trial). Os dois primeiros estão mais vinculados aos fins do processo, os três últimos ostentam uma face instrumental em relação àqueles. A par desses valores específicos, mostram-se ainda significativos para o processo os valores constitucionais e os valores culturais relacionados ao meio onde se insere determinado sistema processual.

A efetividade e a segurança apresentam-se como valores essenciais para a conformação do processo em tal ou qual direção, com vistas a satisfazer determinadas finalidades, servindo também para orientar o juiz na aplicação das regras e princípios. Poder-se-ia dizer, numa perspectiva deontológica, tratar-se de sobreprincípios, embora sejam, a sua vez, também instrumentais em relação ao fim último do processo, que é a realização da Justiça do caso. Interessante é que ambos se encontram

18 A esse respeito, observa DEL VECCHIO, Giorgio. L'homo juridicus. Roma, 1936, p. 11, apud GARCÍA MÁYNEZ, Eduardo. Introducción al estudio del derecho. 4. ed. México: Porrua, 1951, p. 13, que as regras técnicas constituem os meios obrigatoriamente empregados para se conseguir um propósito, mas não prejulgam se é lícito, obrigatório ou ilícito propor-se o fim de que se trate. A técnica, prossegue,nada tem a ver com o valor das finalidades a que serve, pois concerne exclusivamente aos procedimentos que permitem realizá-las, sem se preocupar por esclarecer se são boas ou más. Apreciar o mérito dos fins do indivíduo é problema ético, não técnico. 
em permanente conflito, numa relação proporcional, pois quanto maior a efetividade menor a segurança, e viceversa. Assim, por exemplo, o exercício do direito de defesa, garantia ligada à segurança, não pode ser excessivo nem desarrazoado. Nos casos não resolvidos pela norma, caberá ao órgão judicial, com emprego das técnicas hermenêuticas adequadas, ponderar qual dos valores deverá prevalecer. Na verdade, garantismo e eficiência devem ser postos em relação de adequada proporcionalidade, por meio de uma delicada escolha dos fins a atingir

A segurança liga-se à própria noção de Estado Democrático de Direito, erigida como princípio fundamental da Constituição da República (art. $1^{\circ}$, caput), de modo a garantir o cidadão contra o arbítrio estatal, tendo presente a salvaguarda de elementos fundantes da sociedade realmente democrática, como o princípio democrático, o da justiça, o da igualdade, da divisão de poderes e da legalidade. ${ }^{19}$

Em tal contexto, ganha lugar de destaque o devido processo legal (art. $5^{\circ}$, inciso LIV, da Constituição da República), princípio que exige como corolários a proibição de juízos de exceção e o princípio do juiz natural (art. $5^{\circ}$, incisos XXXVII e LIII), a igualdade (art. $5^{\circ}$, caput), aí compreendida a paridade de armas, ${ }^{20}$ o contraditório e a ampla defesa, com os meios e recursos a ela inerentes (art. $5^{\circ}$, inciso LV), consideradas inadmissíveis as provas obtidas por meios ilícitos (art. $5^{\circ}$, inciso LVI), devendo o litígio ser solucionado por meio de decisão fundamentada (art. 94, inciso IX).

De mais a mais, o desenvolvimento, que se pode julgar excessivo, da pena-

19 Sobre o ponto, SILVA, José Afonso da. Curso de direito constitucional positivo. 5. ed. São Paulo: Revista dos Tribunais, 1989, p. 103-108, e CANOTILHO, J. J. Gomes; MOREIRA, Vital. Fundamentos da constituição. Coimbra: Coimbra, 1991, p. 82-85. HABSCHEID, Walther J. Droit judiciaire privé suisse. Genéve: Librairie de L'Université, 1981, § 50, I, p. 306, tratando da autoridade da coisa julgada, menciona que o Tribunal Federal Constitucional alemão (BverfGE 15,319) sublinhou que o Estado de Direito tem como tarefa preservar a segurança do direito.

20 Para a Corte Européia dos Direitos do Homem, "consoante o princípio da igualdade de armas - um dos elementos da noção mais ampla de processo eqüitativo -, deve ser oferecida a cada uma das partes a possibilidade razoável de apresentar sua causa em condições tais que não a coloquem em situação de desvantagem em relação à outra": Assim, v.g., arestos Dombo Beheer B.V vs. Países-Baixos, de 27.10.1993, série A, n² 274 , $\S 33$, Bulut v. Áustria, de 22.2.1996, Recueil 1996, II, § 47, Foucher vs. França, de 17.3.1997, $\S 34$, Kuopila vs. Finlândia, de 27.4.2000, apud MARCUS-HELMONS, Silvio. Quelques aspects de la notion d'égalité des armes (Un aperçu de la jurisprudence de la Cour européenne des droits de l'homme), in Aux sources du procès équitable une certaine idée de la qualité de la Justice. In: LE PROCÈS équitable et la protection juridictionnelle du citoyen. Bruxelles: Bruylant, 2001, p. 68. 
lização da vida social e política exige sejam as regras jurídicas formuladas de maneira simples, clara, acessível e previsível: daí a noção de Estado de Direito e o princípio da segurança jurídica, produtos de desenvolvimentos sociais cada vez mais complexos e de evoluções cada vez mais incertas. ${ }^{21}$ Numa visão mais abrangente, a ultrapassar o campo estrito do direito processual, o princípio da segurança jurídica encontra-se ligado a duas exigências: qualidade da lei e previsibilidade do direito. Para Bertrand Mathieu e Michel Verpeaux, ${ }^{22}$ decorrem da primeira os seguintes princípios: de claridade, acessibilidade, eficácia e efetividade (confusão entre dois valores antagônicos). Da segunda, os seguintes princípios: da não-retroatividade da lei, da proteção dos direitos adquiridos, da confiança legítima e da estabilidade das relações contratuais.

Advirta-se, porém, que o jurista deve observar a ordem jurídica, atento ao valor da segurança jurídica, sem confundi-la com a manutenção cega e indiscriminada do statu quo. Cumpre não identificar, outrossim, o valor da segurança jurídica com a "ideologia" da segurança, que tem por objetivo o imobilismo social. Não se trata, também. de identificar o Estado com a ordem, e a lei com a justiça, subprodutos do positivismo, com o que se impediria o acolhimento de qualquer direito nãoestatal, bem como a absorção dos reclamos de justiça do povo, a menos que com o expresso beneplácito do legislador. Essa percepção da realidade social revela-se míope e não desejada. A manutenção da ordem jurídica só pode ser realizada mediante questionamentos e aperfeiçoamentos, em consonância com a racionalidade, que certamente passa pelo Estado, mas que vai além dele, atenta aos direitos construídos pelo processo histórico. ${ }^{23}$

É preciso levar em conta, ademais, que a segurança não é o único valor presente no ambiente processual, mormente porque todo o processo é polarizado pelo fim de realizar a justiça material do caso, por meio de um processo equânime e efetivo. De tal sorte, o formalismo excessivo pode inclusive inibir o desempenho dos direitos fundamentais do jurisdicionado.

A sua vez, a efetividade está consagrada na Constituição Federal, art. $5^{\circ}, \mathrm{XXXV}$, pois não é suficiente tãosomente abrir a porta de entrada do Poder Judiciário, n.ıas prestar jurisdição

21 Cf. MATHIEU, Bertrand; VERPEAUX, Michel. Contentieux constitutionnel des droits fondamentaux. Paris, LGDJ, 2002, p. 703, que ressaltam o emprego substancial desses conceitos tanto pelo juiz constitucional francês quanto pelo juiz ordinário.

22 Ibidem, p. 704-718.

23 Reproduzimos, com algumas alterações, a lição exemplar de AZEVEDO, Plauto Faraco de. Poder judiciário e justiça social. Revista da Ajuris, Porto Alegre, n. 63, p. 5-16, mar. 1995, esp.p. 14. 
tanto quanto possível eficiente, efetiva e justa, mediante um processo sem dilações temporais ou formalismos excessivos, que conceda ao vencedor no plano jurídico e social tudo a que faça jus. Além disso, as dificuldades temporais atuais na administração da justiça e a mudança qualitativa dos litígios justificam o inaudito elastecimento da tutela cautelar em nossa época, assim como a concepção de remédios jurisdicionais de índole provisória, autônomos ou não, com caráter antecipatório e satisfativo do pretendido direito. ${ }^{24}$ Advirta-se, além disso, que a efetividade vigora seja em relação ao direito já lesionado seja quanto àquele simplesmente ameaçado (Constituição Federal, artigo $5^{\circ}, \mathrm{XXXV}$ ), abrangendo assim a tutela preventiva substancial e definitiva, além da meramente provisória ou temporária. ${ }^{25}$ Além disso, a perspectiva constitucional do processo veio a contribuir para afastar o processo do plano das construções conceituais e meramente técnicas e inseri-lo na realidade política e social. Tal se mostra particularmente adequado no que diz respeito ao formalismo excessivo, pois sua solução exige o exame do conflito dialético entre duas exigências contrapostas, mas igualmente dignas de proteção, asseguradas constitucionalmente: de um lado, a aspiração de um rito munido de um sistema possivelmente amplo e articulado de garantias "formais" e, de outro, o desejo de dispor de um mecanismo processual eficiente e funcional.

Nessa linha de entendimento, a Corte Européia dos Direitos do Homem em vários pronunciamentos vem proclamando que a Convenção Européia dos Direitos do Homem ostenta por finalidade proteger direitos não mais "teóricos ou ilusórios, mas concretos e efetivos"..26

Para a Corte, a efetividade supõe, além disso, que o acesso à justiça não seja obstaculizado pela complexidade ou custo do procedimento. Tal implica que as limitações, sempre deixadas à margem de apreciação dos Estados nacionais, não podem em nenhum caso restringir o acesso assegurado ao litigante de tal maneira que seu direito a um tri-

24Assinale-se, por exemplo, a Lei n. 8.952, de 13 de dezembro de 1994, consubstanciada no artigo 273 e respectivos parágrafos do CPC e as alterações neles introduzidas pela Lei n. 10.444, de 7.5.2002.

25 Sobre essa instigante problemática, ver MOREIRA, J. C. Barbosa. Tutela sancionatória e tutela preventiva. In: TEMAS de direito processual: $2^{\mathrm{a}}$ série. 2. ed. São Paulo: Saraiva, 1988, p. 21-29.

26 Arestos de 24.7.1968, no caso "lingüístico belga", série A, n 6, p. 31, §§ 3 in fine e 4; Golder vs. Reino-Unido, de 25.2.1975, série A, n 18, p. 18, § 35 in fine; Luedicke, Belkacem e Koç, de 28.11.1978, série A, nº 29, p. 17-18, § 41; Marckx, de 136.1979, série A, nº 31, p. 15, $\S 31$, apud FRAVREAU, Bertrand. Aux sources du procès équitable: une certaine idée de la qualité de la justice. In: LE PROCĖS équitable et la protection juridictionnelle du citoyen. Bruxelles: Bruylant, 2001, p. 11 e nota 3. 
bunal seja atingido em sua própria substância, devendo ser observada "uma relação razoável de proporcionalidade entre os meios empregados e o fim visado". Ainda segundo o Tribunal, o litigante não deve ser impedido "de empregar um recurso existente e disponível", proibindo-se todo "entrave desproporcional a seu direito de acesso ao tribunal". ${ }^{27}$

Impõe-se ressaltar, outrossim, que nos dias atuais vários fatores vêm determinando uma maior prevalência do valor da efetividade sobre o da segurança. Um dos aspectos relevantes é a mudança qualitativa dos litígios trazidos ao Judiciário, numa sociedade de massas, com interesse de amplas camadas da população, a tornar imperativa uma solução mais rápida do processo e a efetividade das decisões judiciais. Outro fator significativo é a própria adoção dos princípios e sua constitucionalização, fenômeno que se iniciou após o término da Segunda Guerra Mundial. A anterior tramitação fechada e a minúcia regulamentadora das atuações processuais (excesso de formalismo) dos códigos processuais, formados em período autoritário ou informados por ideologia dessa espécie, servia ao fim de controle da jurisdição e dos agentes forenses pelo centro do poder político, diminuindo a participação democrática dos sujeitos de direito. Tudo veio a mudar com a emergência dos princípios, considerados nessa nova perspectiva como direitos fundamentais, que podem e devem ter lugar de destaque na aplicação prática do direito, sobrepondo-se às simples regras infraconstitucionais. ${ }^{28}$ Essa mudança de paradigma, que introduz um direito muito mais flexível, menos rígido, determina também uma alteração no que concerne à segurança jurídica, que passa de um estado estático para um estado dinâmico. Assim, a segurança jurídica de uma norma se mede pela estabilidade de sua finalidade, abrangida em caso de necessidade por seu próprio movimento. Não mais se busca o absoluto da segurança jurídica, mas a segurança jurídica afetada de um coeficiente, de uma garantia de realidade. Nessa nova perspectiva, a própria segurança jurídica induz a mudança, a movimento, na medida em que ela está a serviço de um objetivo mediato de permitir a efetividade dos direitos e garantias de um processo equânime. ${ }^{29}$ Em suma, a segurança já não é vista com os olhos do Estado liberal, em que tendia a prevalecer como valor, porque

27 Arestos Levages Prestationș Services vs. França, de 23.10.1996, Recueil, 1996-V, p. 1996-V, p. 1543, § 40, Brualla Gómez de la Torre vs. Agne, de 19.12.1997, § 33, Garcia Manibardo vs. Espanha, de 15.2.2000. apud FRAVREAU, Aux sources..., p. 11 e nota 8. 28 A respeito, FREITAS, Lebre de. Introdução ao processo civil: conceito e princípios gerais à luz do Código revisto. Coimbra: Coimbra, 1996, p. 74-76.

29 BOURSIER, Marie-Emma. Le principe de loyauté en droit processuel. Paris: Dalloz, 2003, p. $408, n^{\circ} 679$. 
não serve mais aos fins sociais a que o Estado se destina. Dentro dessas coordenadas, o aplicador deve estar atento às circunstâncias do caso, pois às vezes mesmo atendido o formalismo estabelecido pelo sistema, em face das circunstâncias peculiares da espécie, o processo pode se apresentar injusto ou conduzir a um resultado injusto.

Por outro lado, o abandono de uma visão positivista e a adoção de uma lógica argumentativa, com a colocação do problema no centro das preocupações hermenêuticas, assim como o emprego de princípios, de conceitos jurídicos indeterminados e juízos de equidade, em detrimento de uma visão puramente formalista na aplicação do direito, haveria obviamente de se refletir no processo.

Decorre daí, em primeiro lugar, a recuperação do valor essencial do diálogo judicial na formação do juízo, que há de frutificar pela cooperação das partes com o órgão judicial e deste com as partes, segundo as regras formais do processo. O colóquio assim estimulado, assinale-se. deverá substituir com vantagem a oposição e o confronto, dando azo ao concurso das atividades dos sujeitos processuais, com ampla colaboração tanto na pesquisa dos fatos quanto na valorização da causa. As diretivas aqui preconizadas reforçam-se, por outro lado, pela percepção de uma democracia mais participativa, com um conseqüente exercício mais ativo da cidadania, inclusive de natureza processual. Além de tudo, revela-se inegável a importância do contraditório para o processo justo, princípio essencial que se encontra na base mesma do diálogo judicial e da cooperação. A sentença final só pode resultar do trabalho conjunto de todos os sujeitos do processo. Ora, a idéia de cooperação além de exigir, sim, um juiz ativo e leal, colocado no centro da controvérsia, importará senão o restabelecimento do caráter isonômico do processo pelo menos a busca de um ponto de equilíbrio. Esse objetivo impõe-se alcançado pelo fortalecimento dos poderes das partes, por sua participação mais ativa e leal no processo de formação da decisão, em consonância com uma visão não autoritária do papel do juiz e mais contemporânea quanto à divisão do trabalho entre o órgão judicial e as partes.

Daí a necessidade de estabelecerse o permanente concurso das atividades dos sujeitos processuais, com ampla colaboração tanto na pesquisa dos fatos quanto na valorização jurídica da causa. Colaboração essa, acentue-se, vivificada por permanente diálogo, com a comunicação das idéias subministradas por cada um deles: juízos históricos e valorizações jurídicas capazes de ser empregados convenientemente na decisão. ${ }^{30}$ Semelhante cooperação, res-

30 Assim, GRASSO, Eduardo. La collaborazione nel processo civile. Rivista di Diritto Processuale, n. 21, p. 580-609, 1966, esp. p. 587. Para Grasso, o processo deve ultrapassar o simples escopo da paz jurídica, devendo também ser direcionado à busca da verdade e da justiça, objetivos só alcançáveis, segundo ele, mediante a colaboração entre as partes e o juiz. 
salte-se, mais ainda se justifica pela complexidade da vida atual.

Entendimento contrário padeceria de vício dogmático e positivista, mormente porque a interpretação da regula iuris, no mundo moderno, só pode nascer de uma compreensão integrada entre o sujeito e a norma, geralmente não unívoca, com forte carga de subjetividade. E essa constatação ainda mais se reforça pelo reconhecimento de que todo direito litigioso apresenta-se incerto de forma consubstancial.

Faceta importante a ressaltar é que a participação no processo para a formação da decisão constitui, de forma imediata, uma posição subjetiva inerente aos direitos fundamentais, portanto é ela mesma o exercício de um direito fundamental."3l Tal participação, além de constituir exercício de um direito fundamental, não se reveste apenas de caráter formal, mas deve ser qualificada substancialmente.

Isso me leva a extrair do próprio direito fundamental de participação a base constitucional para o princípio da colaboração, na medida em que tanto as partes quanto o órgão judicial, como igualmente todos aqueles que participam do processo (serventuários, peritos, assistentes técnicos, testemunhas, etc.), devem nele intervir desde a sua instauração até o último ato, agindo e interagindo entre si com boa-fé e lealdade.

Exemplo interessante da aplicação desse modo de ver encontra-se na jurisprudência do Tribunal Constitucional espanhol. Para aquela Alta Corte, o dever judicial de promover e colaborar na realização da efetividade da tutela jurisdicional não é de caráter moral, mas um dever jurídico constitucional, pois os juízes e tribunais têm a "[...] obrigação de proteção eficaz do direito fundamental $[\ldots]$ ". O cumprimento desse mandato constitucional de proteger o direito fundamental à tutela judicial efetiva, a que têm direito todas as pessoas, há de ser para os juízes e tribunais norte de sua atividade jurisdicional. Por isso, o Tribunal Constitucional fala da necessária colaboração dos órgãos judiciais com as partes na materialização da tutela e também no dever específico de garantir a tutela, dever que impede os órgãos jurisdicionais de adotarem uma atitude passiva nesta matéria. ${ }^{32}$

31 Nesse sentido CANOTILHO, J. J. Gomes. Tópicos de um curso de mestrado sobre direitos fundamentais, procedimento, processo e organização. Boletim da Faculdade de Direito de Coimbra, Coimbra, p. 151-163, 1990, esp. p. 155, com amparo na sugestão do status activus processualis, formulada por P. Häberle.

32 Cf. CHAMORRO BERNAL, Francisco. La tutela judicial efectiva: derechos y garantias procesales derivados del artículo 24.1 de la constitución. Barcelona: Bosch, 1994, p. 329, com menção a diversos precedentes (Ibidem, p. 329-330 e notas 72 a 77). 


\section{O FORMALISMO EXCESSIVO E AS FERRAMENTAS PARA O SEU COMBATE}

Pode acontecer, contudo, e esse é o âmago do problema, que o poder organizador, ordenador e disciplinador do formalismo, em vez de concorrer para a realização do direito, aniquile o próprio direito ou determine um retardamento irrazoável da solução do litígio. Neste caso o formalismo se transforma no seu contrário: em vez de colaborar para a realização da justiça material, passa a ser o seu algoz, em vez de propiciar uma solução rápida e eficaz do processo, contribui para a extinção deste sem julgamento do mérito, obstando a que o instrumento atinja a sua finalidade essencial.

Para afastar as conseqüências nefastas do formalismo excessivo, pernicioso ou negativo, mostra-se necessário que o jurista, o operador prático do direito, muna-se de ferramentas que impeçam tal desvio de perspectiva.

Antes de nada, impõe-se atentar às particularidades do caso concreto no trabalho de adaptação da norma, principial ou não, que por hipótese é geral e abstrata. Realmente, o processo de aplicação do direito mostra-se, necessariamente, obra de acomodação do geral ao concreto, a requerer incessante trabalho de adaptação e até de criação, ${ }^{33}$ mesmo porque o legislador não é onipotente na previsão de todas e inumeráveis possibilidades oferecidas pela inesgotável riqueza da vida. Por essa via, o rigor do formalismo resulta temperado pelas necessidades da vida, assim como o conflito entre o aspecto unívoco das características externas e a racionalização material que deve levar a cabo o órgão judicial, entremeada de imperativos éticos, regras utilitárias e de conveniência ou postulados políticos, que rompem com a abstração e a generalidade. A sua vez, o juiz não é uma máquina silogística nem o processo, como fenômeno cultural, presta-se a soluções de matemática exatidão. Impõe-se rejeitar a tese da mecanicista aplicação do direito. ${ }^{34}$ Semelhante constatação mostra-se válida não só no

33 Ver a propósito o ensaio de CAPPELLETTI, Mauro. Giudice legislatori? Milano: Giuffrè, 1984, passim, onde a questão é amplamente discutida. O problema pertence à teoria geral do direito, ingressando no plano filosófico, e por isso escapa ao tema central do presente trabalho.

34 A respeito da problemática só podemos remeter o leitor às instigantes obras de CALOGREO, Guido. La logica del giudice e il suo controllo in cassazione, cit., e de CAPOGRASSI, Giuseppe. Il problema della scienza del diritto. Roma, Foro Italiano, 1937, o primeiro preocupado com a estrutura lógica do processo jurisdicional e o segundo com a inesgotável riqueza da experiência jurídica. O problema é tratado, em tempos mais recentes, por FERRAJOLI, Luigi. Derecho y razón: teoria del garantismo penal. Traducción Perfecto Andrés Ibañez. Madrid, Trotta, 1995, p. 172-175, passim, advertindo que "em nenhum sistema o juiz é uma máquina automática; concebê-lo como tal significa fazer dele uma máquina cega, presa da estupidez ou, pior, dos interesses e condicionamentos do poder mais ou menos ocultos e, em todo caso, favorecer sua irresponsabilidade política e moral". 
plano estritamente jurídico, vinculado ao equacionamento de questões puramente de direito, como também na própria condução do processo e notadamente no recolhimento e valorização do material fático de interesse para a decisão. A esse respeito, observa-se de maneira exemplar que a maneira como opta o juiz no curso da seleção de informações leva a marca, estigmatizada, de sua versão pessoal. Mesmo a condução do processo nem sempre apresenta face uniforme, variando o ritmo imprimido a partir de elementos só encontradiços na marca individual gravada do magistrado na utilização dos instrumentos processuais, apesar da importância e do caráter cogente com que se lhe dão a produzir os procedimentos na manufatura das decisões e outras manifestações essenciais no manejo do processo. ${ }^{35}$

Talvez com maior evidência, também na formação e apreciação do material fático não se verifica uniformidade. Influem para esse resultado fatores vinculados à própria individualidade do ser humano. De um lado, as informações colhidas não só podem variar em qualidade ou quantidade, como serão acolhidas e selecionadas inevitavelmente do ponto de vista pes- soal do juiz. Ainda que a lei processual busque imprimir desejável uniformidade, a regra só indica o caminho, mas não o passo do caminhante. O subjetivismo, outrossim, revela-se ainda mais presente no próprio conhecer do juiz, na sua atitude epistemológica em face dos fatos, a variar infinitamente conforme sua capacidade intelectual com vistas a compreender, selecionar e combinar as informações e delas extrair as devidas inferências. $O$ mesmo sucede, provavelmente com maior intensidade, na avaliação do material recolhido, tarefa em que, nada obstante a vinculação axiológica do sistema, passam a pesar, ainda que de modo inconsciente, também os próprios valores do órgão judicial, desempenhando papel importante sua sensibilidade pessoal às nuanças do caso. ${ }^{36}$

Esse constante trabalhar do órgão judicial com a incapacidade de previsão pela lei de todas as hipóteses possíveis, com a generalidade da regra e ainda com fatores fáticos incertos e inconstantes, agravado pelos diversos graus de sua capacidade pessoal, tanto na coleta do material probatório quanto na sua seleção e avaliação, evidencia de forma bastante clara os riscos sempre

35 LOPES, Mônica Sette. A equiidade e os poderes do juiz. Belo Horizonte: Del Rey, 1993, p. 207-209.

36 Sobre esse aspecto da subjetividade da atividade do órgão judicial, ver LOPES, $A$ eqüidade..., p. 207 e nota 492, reportando-se à obra de IVAINER, Théodore. L'interprétation des faits en droit: essai de mise en perspective cybernétique des 'lumières du magistrat' Prefácio Jean Carbonnier. Paris: LGDJ, 1988, merecedora de profunda meditação pelos novos ângulos oferecidos ao tema da interpretação judicial dos fatos. 
presentes de um conflito entre o valor do formalismo e o da justiça na solução do caso trazido a consideração. Aliás, a questão torna-se exatamente problematizada na passagem do abstrato ao concreto, quando podem se criar situações-limite, não previstas expressamente em lei, capazes de romper com o sentimento de justiça.

Claro, contudo, que a solução haverá de estar dentro do próprio sistema, pois, nessa matéria, como visto anteriormente, mostra-se inconveniente a atribuição de ampla liberdade ao órgão judicial. No domínio do direito processual, aliás, revela-se particularmente importante o papel do sistema, enquanto capaz de traduzir e realizar a adequação valorativa e a unidade interior da ordem jurídica. ${ }^{37}$ Entendimento contrário desviaria a questão do plano metodológico para situá-la, de forma indesejada, no domínio da simples ideologia, terreno em que as circunstâncias concretas passam a ter um significado excessivo, tudo dependendo do contexto geral em que se inserem, consoante subjetiva valoração atribuída ao status quo. ${ }^{38} \mathrm{O}$ capricho pessoal, insista-se, não só poderia pôr em risco a realização do direito material (pense-se na hipótese de o juiz impedir, a seu bel-prazer, a realização de certas provas) como também fazer periclitar a igualdade das partes no processo, sem falar na afronta a garantias fundamentais do cidadão em face do arbítrio estatal. Nesse aspecto, influi também a excessiva valorização do rito, com afastamento completo ou parcial da substância, conduzindo à ruptura com o sentimento de justiça.

Todavia, esse mesmo sentimento de justiça - apanágio do verdadeiro juiz ${ }^{39}$ - pode servir para eliminar a distância entre a abstração da norma e a concretude do caso trazido a juízo. O sentimento do justo concreto conduz ao problema da eqüidade com função interpretativa-individualizadora. Essa função da eqüidade constitui recurso normal

37 Cf. a concepção de CANARIS, Claus-Wilhelm. Pensamento sistemático e conceito de sistema na ciência do direito. Introdução e Tradução A. Menezes Cordeiro. Lisboa: Calouste, 1989, § $1^{\circ}$, II, 2, p. 23.

38 Este aspecto da questão é ressaltado com argúcia por BOBBIO, Norberto. El problema del positivismo jurídico. Tradución Ernesto Garzón Valdés. Buenos Aires: Eudeba, 1965, p. 27-31. Ainda segundo o notável jusfilósofo, geralmente é considerado formalista quem está contra a mudança; se a mudança é progressiva, o formalista é conservador, se no sentido da reação ou da restauração, o formalista é progressista.

39 Calamandrei costumava recordar que a própria palavra sentenza vem de sentire, a par da palavra sentimento, e chamava a atenção constituir a justiça "criação que nasce de uma consciência viva, sensivel, vigilante, humana. É exatamente esse calor vital, esse sentido de contínua conquista, de vigilante responsabilidade que é necessário prezar e desenvolver no juiz" (CALAMANDREI apud CAPPELLETTI, Mauro. Ideologie nel processo civile. In: PROCESSO e ideologie. Bologna: Il Mulino, 1969, p. 3, nota 1). 
posto à disposição do operador jurídico no processo de aplicação das normas, com vistas à ponderação das particularidades do caso. ${ }^{40} \mathrm{Tal}$ entendimento decorre de atividade conatural ao ato de julgar, expressa na compreensão equitativa da regra de lei, e mais amplamente do direito a aplicar no momento da decisão. Parece adequada a imagem de que nessa aplicação da regra legal, do direito tout court, o sistema funcione como uma língua, isto é, como um sistema de regras de uso das palavras da linguagem jurídica na qual se nomeiam os fatos a serem apreciados e julgados. E isso porque os significados expressos na língua jurídica, empregada na aplicação operativa do direito, são tão ambíguos e opináveis como as regras de uso da língua jurídica ditada pelas normas. ${ }^{41}$

Nessa perspectiva, o juízo de legalidade constata as características essenciais e comuns, enquanto o juízo de eqüidade ocupa-se com a compreensão das características acidentais e particulares da hipótese individual verificada, mas sempre levando em conta o sistema em que inserido. Assim, legalidade e eqüidade apresentam-se como dois aspectos distintos mas logicamente indissociáveis da linguagem jurídica e do significado dos signos nela empregados, de sorte que convivem numa relação necessária e inafastável, um não existindo sem o outro. No fundo, portanto, verifica-se uma falsa contraposição entre formalismo excessivo e informalismo arbitrárịo, já que todos os juízos são ou devem ser mais ou menos equiitativos, ou iníquos, segundo o seu grau de compreensão das conotações específicas e diferenciadas da hipótese posta à apreciação do juiz. ${ }^{42}$

Dentro de tal concepção, a eqüidade desponta como a justiça do caso concreto, como inarredável mediação entre o caráter abstrato do sistema e as exigências das hipóteses singulares e concretas. Transcende-se a justiça abstrata e genérica da lei para alcançar-se a justiça concreta e individualizada do caso, sai-se enfim da legalidade para ingressar no direito.

40 Esse entendimento é pacífico na doutrina brasileira. Neste sentido, podem ser mencionados, e.g., LOPES, A eqüidade..., p. 75 et seq.; DINIZ, Maria Helena. As lacunas no direito. 2 ed. São Paulo: Saraiva, 1989, p. 258-267; BATALHA, Wilson de Souza Campos. Lei de introdução ao Código Civil. [s.n.t.], v. 1, n. 57, p. 384; BARBI, Celso Agrícola. Comentários ao Código de Processo Civil. [s.n.t.] v. 1, p. 318. No plano filosófico, a questão remonta a ARISTÓTELES. Ética Nicomáquea. Tradución esp. J. Pallí Bonet. Madrid: Gredos, 1985, v, 10, 1137b, p. 263.

41 Cf. FERRAJOLI, Derecho..., p. 56. Também a correlação entre a língua e a linguagem interna do sistema mostra-se essencial para a teoria hermenêutica preconizada por FERRAZ JÚNIOR, Tércio Sampaio. Introdução ao estudo do direito: técnica, decisão, dominação. São Paulo; Atlas, 1989, p. 231-281, assentada no teor da tradução.

42 Cf. FERRAJOLI, op. cit., p. 162-163. 
Por outro lado, em direito processual, mais ainda do que em outros ramos do direito, enquanto trabalho de adaptação do geral ao concreto, a eqüidade relaciona-se, intimamente, com os fins da norma e da própria finalidade do processo e da tarefa afeita à jurisdição. Embora o princípio mais alto seja o da justiça, por meio de uma igualdade de todos perante a lei, não se pode esquecer o caráter essencialmente finalístico do direito processual. Finalismo esse não voltado para si mesmo, pois inexiste formalismo em si, senão direcionado para os fins últimos da jurisdição.

A esse respeito, não se pode deixar de salientar que o fim do direito é servir à finalidade pragmática que lhe é própria. Processualmente, visa-se a atingir a um processo equânime, peculiar do Estado democrático de direito, que sirva à idéia de um equilíbrio ideal entre as partes e ao fim material do processo: a realização da justiça material.

Ademais, as formas processuais cogentes não devem ser consideradas "formas eficaciais" (Wirkform), mas "formas finalísticas" (Zweckform), subordinadas de modo instrumental às finalidades processuais, a impedir assim o entorpecimento do rigor formal processual, materialmente determinado, por um formalismo de forma sem conteúdo. A esse ângulo visual, as prescrições formais devem ser sempre apreciadas conforme sua finalidade e sentido ra- zoável, evitando-se todo exagero das exigências de forma. Se a finalidade da prescrição foi atingida na sua essência, sem prejuízo a interesses dignos de proteção da contraparte, o defeito de forma não deve prejudicar a parte. A forma não pode, assim, ser colocada "além da matéria", por não possuir valor próprio, devendo por razões de eqüidade a essência sobrepujar a forma. A não-observância de formas vazias não implica prejuízo, pois a lei não reclama uma finalidade oca e vazia. Na medida em que o ponto de vista da eqüidade concede espaço à discrição judicial, mesmo em se tratando de prescrições formais de natureza cogente, proporciona o instrumento para a superação da até então ameaçadora inflexibilidade da forma, mormente porque a eqüidade (segundo Radbruch) representa a justiça do caso concreto. Uma atitude livre também toma a visão da eqüidade contra a letra da determinação formal. Ela rejeita toda obediência cega ao Código. Por não serem reconhecidos princípios especiais restritivos na hermenêutica das normas formais, a interpretação não deve ser "mesquinha", mas o mais possível "generosa" e livre. ${ }^{43}$

Dentro dessa linha de orientação, decidiu o Tribunal Constitucional espanhol que "[...] as normas que contêm os requisitos formais devem ser aplicadas tendo-se sempre presente o fim pretendido ao se estabelecer ditos re-

43 VOLLKOMMER, Max. Formenstrenge und prozessuale Billigkeit. München: Beck, 1973, p. 10-12, p. 24-27, 30, 32-39, passim. 
quisitos, evitando qualquer excesso formalista que os converteria em meros obstáculos processuais e em fonte de incerteza e imprevisibilidade para a sorte das pretensões em jogo". ${ }^{44}$ Certamente, sempre se verifica uma contraposição entre o ideal e o realizável, e aqui, como na política e em outros campos de atuação do humano, deve prevalecer o lema de que os fins não justificam os meios: o direito material não deve ser realizado à custa dos princípios e garantias fundamentais do cidadão. O informalismo só pode ocorrer se atendida a finalidade jurídica primacial do processo de realização do direito material, em tempo adequado e preservadas as garantias e direitos fundamentais das partes. $\mathrm{E}$ isso porque tal preservação serve ao fïm maior da justiça material da decisão, pois é bem possível, por exemplo, que o contraditório venha a demonstrar que a melhor solução não seria aquela imaginada pelo órgão judicial.
Impõe-se, portanto, a veemente rejeição do formalismo oco e vazio, que desconhece o concreto e as finalidades maiores do processo, descurando de realizar a justiça material do caso.

Se a forma não é oca nem vazia, o que importa é o conteúdo não o nome do ato processual. Significativo avanço nesse campo decorreu da célebre decretal do Papa Alexandre III, de 1160 , Livro II, tít. I, de judiciis, cap. VI, ao dispensar as partes de exprimir no libelo o nome da ação, bastando a proposição clara do fato motivador do direito de agir $^{45}$ e da qual exsurge princípio hoje fundamental: em direito processual, o nome atribuído à parte ao ato processual, embora equivocado, nenhuma influência haverá de ter, importando apenas o seu conteúdo. De outro lado, o seu invólucro exterior, a maneira como se exterioriza, também perdeu terreno para o teor interno. ${ }^{46}$

Por sua vez, tanto a organização do processo quanto o seu ordenamento e

44 Sentença 57, de 8.5.1984, na linha de outros precedentes, como ressalta CHAMORRO BERNAL, La tutela....p. 315. Adiante, refere que o mesmo tribunal entendeu haver excesso de formalismo na inadmissão de recurso por faltar 360 pesetas num preparo de 327.846 . (Ibidem, p. 317).

45 Mencionada por ALMEIDA JÚNIOR, João Mendes de. Direito judiciário brasileiro. 5. ed. adaptada por João Mendes Neto. Rio de Janeiro: Freitas Bastos, 1960, p. 133. BRIEGLEB, Hans Karl. Einleitung in die Theorie der summarischen Processe. Leipzig: Tauchnitz, 1859, Nachdruck des Verlages Ferdinand Keip, Frankfurt a. M., 1969, §7, p. 20, assim a reproduz: "Nomen actionis in libello exprimere pars non cogitur; debet tamen factum ita clare proponere, ut ex eo jus agendi colligatur".

46 Como sublinha BLOMEYER, Arwerd. Zivilprozessrecht: Erkenntnisverfahren. Berlin: Springer, 1963, §30, IV, p. 139, nota 2, reportando-se à jurisprudência alemã, quando a lei exige determinadas declarações não é necessário, por tal motivo, o emprego de "palavras solenes e determinadas". 
disciplina também não são destituídos de conteúdo. Ordem pela ordem não tem significado. Assim, se o juiz preservar as garantias das partes, vedado não lhe é adotar um ponto de vista mais maleável, adaptando o rigor formal ao caso, quando necessário para vencer o formalismo, obstaculizador da justiça na hipótese concreta. Dentro dessa visão finalista, bem ressalta a melhor doutrina brasileira que o capítulo mais importante e fundamental de um Código de Processo moderno encontra-se nos preceitos relativizantes das nulidades, integrando-se as regras referentes às nulidades no "sobredireito" processual, porque se sobrepõem às demais, por interesse público eminente, condicionando-lhes, sempre que possivel, a imperatividade. ${ }^{47}$
Aliás, cumpre advertir que rigor formal não significa interpretação "estrita" da lei processual. ${ }^{48}$ Não só admissível interpretação sistemática e teleológica, como se impõe observada a mudança do sentido da lei pela alteração das idéias éticas fundamentais, devendo o trabalho hermenêutico jamais esquecer as linhas mestras do sistema constitucional, suas garantias e princípios, normas valorativas primaciais para a concretização de conceitos jurídicos indeterminados, preenchimento de lacunas e interpretação em geral da lei processual. ${ }^{49}$

De tudo que foi dito e analisado impõe-se afastar o formalismo oco e vazio, incapaz de servir às finalidades essenciais do processo - relativizada assim qualquer invalidade daí decorrente-, mormente quando atente contra

47 Cf. LACERDA, Galeno. O Código e o formalismo processual. Revista da Ajuris, Porto Alegre, n. 28, p. 7-14, 1983, esp. p. 11, e sua inspirada adaptação analógica do conceito de Ernst Zitelmann para definir as normas de direito internacional privado: direito sobre direito (Recht über Recht).

48 Sobre o ponto, COUTURE, Eduardo J. Interpretación de las leyes procesales. In: ESTUDIOS de derecho procesal civil. 3 ed. Buenos Aires, Depalma, 1989, v. 3, p. 14-65, esp. p. $48-52$, p. 58-59, p. 62-64, dando adequado destaque aos princípios processuais na tarefa hermenêutica.

49 Assim, ROSENBERG-SCHWAB. Zivilprozessrecht. 12. aufl. München: Beck, 1977, § 7, II, p. 30-31. Para eles a interpretação correta deve ser procurada pelo balanceamento dos princípios processuais e ético-jurídicos, como a igualdade de tratamento das partes, a clareza e segurança do procedimento, do rigor formal, da eqüidade, da tutela da boa fé, da economia processual, e de uma solução rápida e definitiva do processo assim como da economia de custos e de trabalho. Esse balanceamento pressupõe também a averiguação do interesse dos participantes e da sociedade. Nessa tarefa, as decisões contrárias materialmente ou lacunas valorativas da lei devem ser resolvidas construtivamente por meio de interpretação. Para isso devem ser empregados, principalmente, a analogia, o argumento a contrario e a redução teleológica. Se não encontrados pontos de apoio na lei, decide por último a própria valoração livre do intérprete com consideração das idéias de justiça dominantes na jurisprudência e na doutrina. 
os princípios e valores imperantes no ambiente processual, a exemplo da efetividade, da segurança, da boa-fé e lealdade e do princípio do processo justo. O que importa, ao fim e ao cabo, é o formalismo-valorativo.

De tal sorte, o formalismo excessivo deve ser combatido com o emprego da equidade com função interpretativaindividualizadora, tomando-se sempre como medida as finalidades essenciais do instrumento processual (processo justo e equânime, do ponto de vista processual, justiça material, do ponto de vista material), e os princípios e valores que estão à sua base, desde que respeitados os direitos fundamentais da parte e na ausência de prejuízo.

Interessante aplicação do princípio da finalidade essencial vem sendo implementada pelos juízes de direito de Porto Alegre que geralmente convertem de oficio o procedimento sumário em ordinário. $\mathrm{E}$ a decisão decorre de interpretação construtiva do art. 244 do CPC, argumentando-se que, diante das dificuldades da estrutura judiciária, atingir-se-á de modo mais cabal a finalidade do processo sumário - uma mais rápida e eficiente solução da controvérsia judicial - com a adoção do rito ordinário. A solução, com ser engenhosa, parece estar dentro dos limites do sistema, ainda mais que aumenta as possibilidades de defesa do demandado e não implica qualquer prejuízo a algum princípio processual fundamental. Em suma, no caso, a efetividade serve à segurança e relativiza a eventual nulidade decorrente da alteração do procedimento. Nem se argumente com um eventual interesse público na preservação do rito, do due process of law, como um valor absoluto e abstrato. Como bem acentua Galeno Lacerda, certa, sem dúvida, a presença de interesse público na determinação do rito. Mas, acima dele, se ergue outro, também público, de maior relevância: o de que o processo sirva, como instrumento, à justiça humana e concreta, a que se reduz, na verdade, sua única e fundamental razão de ser. ${ }^{50}$

Outro exemplo notável desse trabaIho de adaptação estampa-se no acórdão unânime da $4^{\mathrm{a}}$ Turma do Superior Tribunal de Justiça, ${ }^{51}$ em que, à vista das circunstâncias especiais do caso concreto, afastou-se a decadência de ação rescisória, porque a intempestividade do recurso extraordinário, admitido por força de agravo, fora declarada um decênio depois, não tendo se dado por unanimidade e baseada em interpretação discutível. A ementa do julgado mostra-se bastante expressiva: "Processo Civil. Ação rescisória. Recurso inadmitido por intempestividade. Início do

50 LACERDA, O Código..., p. 10.

51 BRASIL. Superior Tribunal de Justiça. REsp 299-RJ. Relator: Min. Sálvio de Figueiredo. J. 28 ago. 1989. Revista de Jurisprudência do Superior Tribunal de Justiça, Brasília, n. 4, p. 1554-1562, 1989. 
prazo decadencial. Correntes. Exegese. Mesmo quando se perfilha a corrente segundo a qual o prazo decadencial para o ajuizamento da rescisória se conta do trânsito em julgado da decisão e não do acórdão que não conheceu, por intempestivo, do recurso, uma vez que a interposição extemporânea desse não elide o trânsito já consumado. circunstâncias especiais do caso concreto podem afastar o reconhecimento da decadência. A melhor interpretação da lei é a que se preocupa com a solução justa, não podendo o seu aplicador esquecer que o rigorismo na exegese dos textos legais pode levar a injustiças."

Por outro lado, constitui exemplo emblemático de formalismo excessivo a extinção do processo sem julgamento do mérito, depois de realizada a prova, em primeiro ou segundo grau de jurisdição, somente por considerações de ordem formal, com absoluta prevalência do meio sobre o fim. Nessa fase adiantada do processo, nenhuma razão justifica o reconhecimento da inadequação da forma especial (por exemplo: a inadequação de ação regressiva pela via da denunciação da lide, por não se tratar de garantia própria, com introdução de fundamento novo ou matéria nova), se já existem todos os elementos necessários ao pronunciamento de mérito. Para que afrontar os princípios da efetividade e da economia processual e começar tudo de novo em outro juízo, quando já é possível o pronunciamento sobre o mérito, com a realização das finalidades essenciais do processo? Apenas por que a forma denunciação da lide não é admitida, e sim a forma ação autônoma de regresso? Todavia, o próprio Código dá resposta adequada à indagação. Consoante o disposto na regra contida no art. 250 do $\mathrm{CPC}$, o erro de forma do processo acarreta unicamente a anulação dos atos que não possam ser aproveitados, devendo praticarse os que forem necessários, a fim de se observarem, quanto possível, as prescrições legais. Mesmo assim, e o ponto é assaz importante, nos termos do parágrafo único do mesmo dispositivo, dar-se-á o aproveitamento dos atos praticados, desde que não resulte prejuízo à defesa.

Essas considerações também são válidas para a hipótese em que o autor, dispondo embora de título executivo extrajudicial, opte por propor ação de conhecimento. Como bem ressalta a respeito Humberto Theodoro Jr., soa falso, diante do processo civil contemporâneo, defender a carência de ação de cognição por parte do credor simplesmente em razão de dispor de título executivo extrajudicial que, de modo algum, o isenta de disputas e questionamentos no que se relaciona com o negócio jurídico subjacente. O interesse necessário ao manejo de qualquer ação está na necessidade que toca à parte de recorrer ao processo jurisdicional para evitar um dano jurídico. É a existência do litígio que representa essa possibilidade de dano. Como a previsão de execução forçada não impede a formação do litígio entre credor e devedor, continuam as partes - tanto o credor como o devedor - com a possibilidade 
de, antes ou independentemente da execução, recorrerem ao processo de conhecimento para obter o definitivo acertamento de suas posições jurídicas na ordem material. ${ }^{52}$ Impende acrescentar a essas judiciosas observações que, tendo eventualmente tramitado o processo e atingido sua finalidade essencial, a sua extinção sem julgamento do mérito, por falta de interesse, implicaria no fundo formalismo excessivo, oco e vazio.

Por outro lado, o formalismo-valorativo, informado nesse passo pela lealdade e boa-fé, que deve ser apanágio de todos os sujeitos do processo, não só das partes, ${ }^{53}$ impõe, como visto anteriormente, a cooperação do órgão judicial com as partes e destas com aquele. Esse aspecto é por demais relevante no Estado democrático de direito, que é tributário do bom uso pelo juiz de seus poderes, cada vez mais incre- mentados pelo fenômeno da incerteza e complexidade da sociedade atual e da inflação legislativa, com aumento das regras de equidade e aplicação dos princípios. Exatamente a lealdade no emprego dessa liberdade nova atribuída ao órgão judicial é que pode justificar a confiança atribuída ao juiz na aplicação do direito justo. ${ }^{54}$ Ora, tanto a boa-fé quanto a lealdade do órgão judicial seriam flagrantemente desrespeitadas sem um esforço efetivo para salvar o instrumento dos vícios formais.

Do mesmo modo, dentro dessa visão cooperativa, impõe-se ao juiz mandar suprir qualquer falha na formação do instrumento que acompanha o recurso de agravo, quando se trate de peça não obrigatória, embora necessária para o julgamento. ${ }^{55} \mathrm{O}$ ideal, por sinal, seria que essa atividade saneadora do juiz se estendesse também às peças

52 THEODORO JÚNIOR., Humberto. Tutela diferenciada: opção do credor entre a ação executiva e a ação ordinária de cobrança. In: STUDI di diritto processuale civile in onore di Giuseppe Tarzia. Milano: Giuffrè, 2005, p. 2527-2548.

53 Note-se que o art. 14 do CPC, redação da Lei n. 10.358, de 27.12.2001, imputa o dever de proceder com lealdade e boa-fé a "todos aqueles que de qualquer forma participam do processo". 54 Sobre essa nova realidade, a tese fundamental de BOURSIER, Le príncipe..., p. 372377 , passim.

55 Merece aplausos a orientação atual do STJ, adotada pela Corte Especial, no julgamento do BRASIL. Superior Tribunal de Justiça. EREsp 433687-PR. Relator para o acórdão: Min. Fernando Gonçalves. J. em: 5 maio 2004. DJU 4 abr. 2005, p. 157, decisão encimada desta significativa ementa:" PROCESSUAL CIVIL. AGRAVO DE INSTRUMENTO. PEÇAS FACULTATIVAS. ESSENCIAIS AO JULGAMENTO. JUNTADA POSTERIOR. OPORTUNIZAÇÃO. POSSIBILIDADE. 1 - A falta de peças essenciais ao julgamento, mas de colação facultativa, não previstas no art. 525 , I do CPC, somente obsta o conhecimento do agravo se, oportunizada a sua juntada, queda-se inerte a parte interessada. 2 -Embargos de divergência conhecidos e recebidos para determinar a intimação do agravante, a fim de juntar os documentos considerados indispensáveis". 
obrigatórias, o que contudo depende de reforma legislativa. ${ }^{56}$

Também em homenagem ao princípio da boa-fé e lealdade, não pode o juiz elastecer, além do razoável, os pressupostos de admissibilidade do recurso, para facilitar o seu trabalho. Assim, se a semelhança dos casos confrontados diz respeito ao núcleo do direito, demonstrando a necessidade de uniformização jurisprudencial (nos casos, v.g., de recurso especial por dissídio de julgados ou de embargos de divergência), inadmissível não conhecer do recurso porque se verifica dessemelhança em pontos fáticos irrelevantes.

A boa-fé e a lealdade impedem, ainda, a criação de situações que impliquem verdadeira armadilha procedimental, fazendo o processo sucumbir a exigências meramente formais, distantes da verdadeira finalidade da lei e estabelecidas por meio de raciocínios elaborados para dar à norma sentido completamente diverso. A matéria está também vinculada à transparência e claridade na aplicação do direito, aspectos ligados à segurança jurídica.

Veja-se. por exemplo, a questão da possibilidade de interposição do recurso via fac-simile, instituída pela Lei $\mathrm{n}$. 9.800 , de 26 de maio de 1999. Num país de dimensões continentais como o Brasil, procurou-se facilitar a vida dos cidadãos, permitindo-se a transmissão do recurso com o emprego de sistema de transmissão de dados e imagens, dentro do prazo do recurso, e mediante entrega dos originais em juízo "necessariamente até cinco dias da data do seu término", isto é, da data do término do prazo do recurso (Lei n. 9.800/1999, art. $\left.2^{\circ}\right)$. Essa é a finalidade essencial da inovação. O prazo para juntada dos originais só será contado da data da recepção do material se o ato não estiver sujeito a prazo, o que evidentemente não abrange os recursos (Lei n. 9.800/1999, $\S$ único do art. $2^{\circ}$ ). Invocando, porém, o princípio da consumação, parte da jurisprudência do STJ inverteu totalmente o sentido da lei e praticamente revogou o mencionado art. $2^{\circ}$, para entender que, em todas as hipóteses, o prazo para entrega dos originais deverá ser de até cinco dias da data da recepção do material. Bem de ver, no entanto, que a preclusão consumativa decorre de que o exercício da faculdade determinou fosse alcançada a finalidade do ato, o que consumaria o interesse na sua prática. ${ }^{57} \mathrm{Na}$ espécie em comento, no entanto, não se trata de praticar novamente $o$ ato, mas de juntar o ori-

56 O CPC português, na feição adquirida depois das reformas de 1996 e 1997, ao instituir a cooperação como princípio basilar (art. 266) não descurou de determinar salutarmente no art. 742,4 , que "Se faltar algum elemento que o tribunal superior considere necessário ao julgamento do recurso, requisitá-lo-á por simples ofício".

57 GUARNERI, Giuseppe. Preclusione (diritto processuale penale). In: NOVISSIMO digesto italiano. Napoli: UTET, [s.d.], v. 13, p. 570-576, esp. p. 574. 
ginal da cópia antes enviada, hipótese em que a própria lei cuidou de resguardar o efeito consumativo permitindo a entrega dessa peça cinco dias após o término do prazo do recurso. O interesse continua existindo porque não basta o envio da cópia, sendo imprescindível a remessa do original, para que a finalidade do ato seja alcançada. Ademais, a desagradável, e às vezes terrível surpresa, de ver o recurso não conhecido por intempestividade, nada tem a ver com a visão cooperativa do processo, única capaz de conduzir a uma efetividade virtuosa e não simplesmente perniciosa, preocupada esta somente com a performance, com a estatística, mas não com os valores fundamentais do processo. Seria importante uma reflexão a respeito do assunto, em prol inclusive da necessária legitimação do Poder Judiciário perante a sociedade civil, de fundamental importância no Estado democrático de direito.

Também o princípio da segurança pode afastar o formalismo excessivo.

Inaceitável, portanto, não conhecer do recurso porque o carimbo autenticador, de lavra do próprio tribunal, está ilegível. À evidência, não pode a parte pagar por erro da secretaria do tribunal. Mormente, porque a tanto impede o princípio da confiança legítima, corolário do princípio da segurança. A isso se ajunta o princípio da cooperação, a que está obrigado o órgão judicial. Cumpre, portanto, em tal hipótese, a se pretender afastar os riscos de um processo de caráter dualístico e privado, já ultrapassado, determinar até de ofício seja a dúvida esclarecida pela parte interessada.

Se a parte, ao ingressar com agravo, relacionou as peças que formam o instrumento, entre elas todas as obrigatórias, seria inadmissível não fosse conhecido o recurso por faltante uma destas, quando o processo chegou ao relator. A parte não pode ser prejudicada por falha da secretaria ou do tribunal e a confiança legítima nos atos da administração, corolário do princípio da segurança, assim como o princípio da cooperação, impõe seja reaberto prazo para a erradicação da falta.

A aplicação do princípio da confiança legítima também é de utilidade nos equívocos nas informações processuais prestadas por rede de computadores operadas pelo Poder Judiciário, como ocorre no Estado do Rio Grande do Sul, porque estas podem induzir em erro o usuário e provocar a perda de prazo. Em tal hipótese, aplicando-se o princípio e o disposto no art. 183, $2^{\mathrm{a}}$ parte, e respectivos parágrafos, é possível reconhecer justa causa e relevar a falta. ${ }^{58}$

58 Aplicando o princípio da confiança em casos dessa espécie, o RIO GRANDE DO SUL. Tribunal de Justiça. $6^{a}$ Câm. Cív. Al 70005354 196. Relator: Des. C. A. Alvaro de Oliveira. 27 ago. 2003, v.u.; BRASIL. Superior Tribunal de Justiça. $1^{\text {a }}$ T. REsp 390.561. Relator: Min. Humberto Gomes de Barros. DJU 26 ago. 2002 p. 175: BRASIL. Superior Tribunal de Justiça. 4a. Turma. REsp 49.456/DF. Relator: Min. Barros Monteiro. J. em: 25 out. 1994. DJU 19 dez. 1994, p. 35.321 ; em contrário, entre outros, RIO GRANDE DO SUL. Tribunal de Justiça. $6^{\mathrm{a}}$ Câm. Cív. AC 70008133027, Redator para o acórdão: Des. Palmeiro da Fontoura. 9 jun/2004. 
Exemplo paradigmático, tanto de excesso de formalismo quanto de sua correção pelas normas maiores do sistema brasileiro, ocorreu no Rio Grande do Sul. Em determinada demanda movida contra esse Estado, seis antigas assistentes judiciárias reclamaram o reconhecimento do direito de opção pela carreira de defensor público, assegurado no art. 22 do Ato das Disposições Constitucionais Transitórias anexo à Constituição de 1988. O ente estatal, ao contestar a demanda, reconheceu a situação fática inconteste das autoras, mas lhes negou o direito, ao argumento de que a norma transitória só albergaria os funcionários concursados, não aqueles em desvio de função. No juízo de apelação, órgão fracionário do Tribunal de Justiça entendeu de acolher o pedido em relação a quatro das postulantes. Rejeitou, porém, o pedido de duas delas, sob o fundamento de inexistência de prova do desempenho das funções de defensoria pública anteriormente à instalação da Assembléia Nacional Constituinte, considerando despida de eficácia a admissão da contestação por se tratar de ente estatal, incidindo o disposto no parágrafo único do art. 302 do Código de Processo Civil. Verificou- se, portanto, um giro de cento e oitenta graus, porquanto se tornara incontroverso nos autos o próprio suporte fático da regra constitucional transitória. A parte surpreendida ainda tentou elucidar o juízo interpondo embargos declaratórios, ao qual anexou certidão passada pelo Estado comprovando a circunstância fática reclamada pela decisão. O recurso, porém, não logrou êxito, pois a Câmara julgadora entendeu ter passado o momento próprio para a apresentação de documentos, não se podendo emprestar efeito infringente a essa modalidade de inconformidade. $\mathrm{O}$ acerbado conflito entre justiça e formalismo encontrou exemplar corretivo em decisão do $2^{\circ}$ Grupo Cível do mesmo Tribunal, por via do remédio excepcional da ação rescisória. ${ }^{59}$ Prevaleceu a tese de que fora infringido o princípio do contraditório, pois o órgão judicial não poderia ter surpreendido a parte, sem ouvi-la previamente, em questão de fato fundamental para a decisão. ${ }^{60}$

Se o nome não importa, e sim o conteúdo, constitui sinal indiscutível de formalismo excessivo deixar de receber como arresto o pedido de apreensão e depósito de algum bem para prevenir dano, com vistas a assegurar a futura

59 RIO GRANDE DO SUL. Tribunal de Justiça. Ação rescisória n. 595132226. Redator designado: Des. José Maria Rosa Tesheiner, com substancioso voto de vista do Des. Araken de Assis. J. em: 10 maio 1996. Revista Forense, Rio de Janeiro, n. 338, p. 301-309, abr./jun. 1997. em que atuou como advogado das autoras o autor destas linhas.

60 Trata-se, efetivamente, de um novo conceito, mais dilargado, do princípio do contraditório, hoje adotado na doutrina e na prática judiciária européia. Ver a respeito OLIVEIRA, Carlos Alberto Alvaro de. O juiz e o princípio do contraditório. [s.n.t.] 
execução de provável crédito. Da mesma impropriedade padece o indeferimento de pedido de arresto por não atender às abstrusas exigências do art. 813 do CPC, ao argumento de que se deveria ter arrimado no poder cautelar geral do juiz previsto no art. 798. O nome é o que menos importa!

\section{CONCLUSÃO}

Em conclusão pode-se afirmar que o sistema brasileiro dispõe de meios suficientes para vencer o formalismo pernicioso e conduzir o processo a suas reais metas. Mostra-se necessária, tão-somente, uma atitude mais aberta, talvez uma mudança de mentalidade, para o enfrentamento de problemas dessa ordem.

Advirta-se, no entanto, que o juiz não pode ser arbitrário e desprezar o formalismo virtuoso, a seu bel prazer. Por isso mesmo, a solução da situação problemática, gerada pela antinomia entre a justiça e o formalismo concreto encontra encaminhamento e solução apenas dentro do discurso jurídico, proferido este com a linguagem que lhe é própria. Não se esqueça que a apreensão hermenêutica da realidade, inclusive a jurídica, só é possível porque o sujeito cognoscente conhece de antemão a linguagem em jogo e o alcance da instrumentação nela empregada. ${ }^{61} \mathrm{E}$ o discurso jurídico só obriga até onde conduza a sua força de intrínseca persuasão, força vinculante que há de assentar no sistema jurídico (constitucional e infraconstitucional), nas valorações e princípios dele emanantes, e nas valorações sociais e culturais dominantes no seio da coletividade, enfim no direito como totalidade, para que tudo não redunde a final em puro arbítrio. ${ }^{62}$ Nesse difícil, mas necessário equilíbrio, em que exerce papel fundamental o dever de motivação adequada do ato judicial, habita a força e a legitimação da justiça perante a sociedade civil.

\section{REFERÊNCIAS}

ALMEIDA JÚNIOR, João Mendes de. Direito judiciário brasileiro. 5. ed. adaptada por João Mendes Neto. Rio de Janeiro: Freitas Bastos, 1960.
ARISTÓTELES. Ética Nicomáquea. Tradución esp. J. Pallí Bonet. Madrid: Gredos, 1985.

61 GADAMER, Hans-Georg. Wahrheit und Methode. 4. ed. 1975, p. 250 et seq. apud MENEZES CORDEIRO, A. Introdução. In: CANARIS, Claus-Wilhelm. Pensamento sistemático e conceito de sistema na ciência do direito. Lisboa: Calouste, 1989, p. LIV. 62 Ver a respeito o excelente prefácio do tradutor português, MACHADO, J. Baptista. Prefácio. In: ENGISCH, Karl. Introdução ao pensamento jurídico. 2. ed. Lisboa: Calouste Gulbenkian, 1968, p. XXIII, nota 4.. quando trata da descoberta do direito praeter legem e contra legem, esp. p. LVII e LVIII. 
AZEVEDO, Plauto Faraco de. Poder judiciário e justiça social. Revista da Ajuris, Porto Alegre, n. 63, p. 5-16, mar. 1995.

BAUR, F. Funktionswandel des Zivilprozesses? In: BEITRÄGE zur Gerichtsverfassung und zum Zivilprozessrecht. Tübingen: J.C.B. Mohr, 1983.

BERLIN, Isaiah. A busca do ideal. In: HARDY, Henry (Org.) Limites da utopia: capítulos da história das idéias. Tradução Valter Lellis Siqueira. São Paulo: Companhia das Letras, 1991.

BLOMEYER, Arwerd. Zivilprozessrecht: Erkenntnisverfahren. Berlin: Springer, 1963.

BOBBIO, Norberto. El problema del positivismo juridico. Tradución Ernesto Garzón Valdés. Buenos Aires: Eudeba, 1965.

BOURSIER, Marie-Emma. Le principe de loyauté en droit processuel. Paris: Dalloz, 2003.

BRIEGLEB, Hans Karl. Einleitung in die Theorie der summarischen Processe. Leipzig: Tauchnitz, 1859.

CALAMANDREI, Piero. Istituzioni di diritto processuale civile. In: OPERE giuridiche. Napoli: Morano, 1970.v. 4.

La genesi logica della sentenza civile, In: Opere giuridiche. Napoli: Morano, 1965. v. 1.

CANARIS, Claus-Wilhelm. Pensamento sistemático e conceito de sistema na ciência do direito. Introdução e Tradução A. Menezes Cordeiro. Lisboa: Calouste, 1989.

CANOTILHO, J. J. Gomes. Tópicos de um curso de mestrado sobre direitos fundamentais, procedimento, processo e organização. Boletim da
Faculdade de Direito de Coimbra, Coimbra, p. 151-163, 1990.

CANOTILHO, J. J. Gomes; MOREIRA, Vital. Fundamentos da constituição. Coimbra: Coimbra, 1991.

CAPOGRASSI, Giuseppe. Il problema della scienza del diritto. Roma, Foro Italiano, 1937.

CAPPELLETTI, Mauro. Giudice legislatori? Milano: Giuffrè, 1984.

. Ideologie nel processo civile. In: PROCESSO e ideologie. Bologna: Il Mulino, 1969.

CHAMORRO BERNAL, Francisco. $\mathrm{La}$ tutela judicial efectiva: derechos y garantias procesales derivados del artículo 24.1 de la constitución. Barcelona: Bosch, 1994.

COUTURE, Eduardo J. Interpretación de las leyes procesales. In: ESTUDIOS de derecho procesal civil. 3. ed. Buenos Aires, Depalma, 1989. v. 3.

DINAMARCO, Cândido R. $A$ instrumentalidade do processo. 2. ed. rev. e atual. São Paulo: Revista dos Tribunais, 1990.

DINIZ, Maria Helena. As lacunas no direito. 2. ed. São Paulo: Saraiva, 1989. BATALHA, Wilson de Souza Campos. Lei de introdução ao Código Civil. [s.n.t.]. v. 1. BARBI, Celso Agrícola. Comentários ao Código de Processo Civil. [s.n.t.] v. 1.

FABRI, Giovanni. Potere del giudice (dir. proc. civ.). In: ENCICLOPEDIA del diritto. Milano: Giffrè, 1985. v. 34.

FERRAJOLI, Luigi. Derecho y razón: teoria del garantismo penal. Traducción Perfecto Andrés Ibañez. Madrid, Trotta, 1995.

FERRAZ JÚNIOR, Tércio Sampaio. Introdução ao estudo do direito: 
técnica, decisão, dominação. São Paulo; Atlas, 1989.

FRAVREAU, Bertrand. Aux sources du procès équitable: une certaine idée de la qualité de la justice. In: LE PROCÈS équitable et la protection juridictionnelle du citoyen. Bruxelles: Bruylant, 2001.

FREITAS, Lebre de. Introdução ao processo civil: conceito e princípios gerais à luz do Código revisto. Coimbra: Coimbra, 1996.

GARCÍA MÁYNEZ, Eduardo. Introducción al estudio del derecho. 4. ed. México: Porrua, 1951.

GAUL, Hans F. Zur Frage nach dem Zweck des Zivilprozesses. Archiv für die Civilistische Praxis, n. 168, p. 27-62, 1968.

GRASSO, Eduardo. La collaborazione nel processo civile. Rivista di Diritto Processuale, n. 21, p. 580-609, 1966.

GUARNERI, Giuseppe. Preclusione (diritto processuale penale). In: NOVISSIMO digesto italiano. Napoli: UTET, [s.d.]. v. 13. p. 570-576.

HABSCHEID, Walther J. Droit judiciaire privé suisse. Genéve: Librairie de L'Université, 1981.

IVAINER, Théodore. L'interprétation des faits en droit: essai de mise en perspective cybernétique des 'lumières du magistrat' Prefácio Jean Carbonnier. Paris: LGDJ, 1988.

JHERING, Rudolf von Geist des römischen Rechts auf den verschiedenen Stufen seiner Entwicklung. Aalen: Scientia Verlag, 1968.

LACERDA, Galeno. O Código e o formalismo processual. Revista da Ajuris, Porto Alegre, n. 28, p. 7-14, 1983.

. Processo e cultura. Revista de Direito Processual Civil, São Paulo, n. 3, p. 74-86, 1962.
LOPES, Mônica Sette. A eqüidade e os poderes do juiz. Belo Horizonte: Del Rey, 1993.

MACHADO, J. Baptista. Prefácio. In: ENGISCH, Karl. Introdução ao pensamento jurídico. 2. ed. Lisboa: Calouste Gulbenkian, 1968,

MARCUS-HELMONS, Silvio. Quelques aspects de la notion d'égalité des armes (Un aperçu de la jurisprudence de la Cour européenne des droits de l'homme), in Aux sources du procès équitable une certaine idée de la qualité de la Justice. In: LE PROCÈS équitable et la protection juridictionnelle du citoyen. Bruxelles: Bruylant, 2001.

MATHIEU, Bertrand; VERPEAUX, Michel. Contentieux constitutionnel des droits fondamentaux. Paris, LGDJ, 2002.

MENEZES CORDEIRO, A. Introdução. In: CANARIS, Claus-Wilhelm. Pensamento sistemático e conceito de sistema na ciência do direito. Lisboa: Calouste, 1989.

MOREIRA, J. C. Barbosa. Tutela sancionatória e tutela preventiva. In: TEMAS de direito processual: $2^{\mathrm{a}}$ série. 2. ed. São Paulo: Saraiva, 1988.

OLIVEIRA, Carlos Alberto Alvaro de. Do formalismo no processo civil. 2. ed. São Paulo: Saraiva, 2003.

O juiz e o princípio do contraditório. [s.n.t.]

O processo civil na perspectiva dos direitos fundamentais. Revista Forense, Rio de Janeiro, n. 372, p. 77-86, mar.abr. 2004.

PICARD, Nicola. Processo civile (dir. moderno). In: ENCICLOPEDIA del diritto. Milano: Giuffrè, 1987. v. 36. 
POLLAK, Rudolf. Sistem des Österreichischen Zivilprozessrechtes. 2. ed. Wien: Manz, 1932.

REALE, Miguel. Fundamentos do direito. 3. ed. São Paulo: Revista dos Tribunais, 1998.

ROSENBERG-SCHWAB. Zivilprozessrecht. 12. aufl. München: Beck, 1977.

SCHIMA, Hans. Compiti e limiti di una teoria generale dei procedimenti. Rivista Trimestrale di Diritto e Procedura Civile, Milano, n. 7, p. 757-772, 1953.

SCHMIDT, Eike Der Zweck des Zivilprozess und seine Ökonomie. Tübingen: Athenäum, 1973.

SILVA, Carlos Augusto. O processo civil como estratégia de poder: reflexo da iudicialização da política no Brasil. Rio de Janeiro: Renovar, 2004.
SILVA, José Afonso da. Curso de direito constitucional positivo. 5. ed. São Paulo: Revista dos Tribunais, 1989.

STEIN, Friedrich. Das Private Wissen des Richters: Untersuchungen zum Beweisrecht beider Prozesse, 2. Aalen: Scientia, 1987.

THEODORO JÚNIOR., Humberto. Tutela diferenciada: opção do credor entre a ação executiva e a ação ordinária de cobrança. In: STUDI di diritto processuale civile in onore di Giuseppe Tarzia. Milano: Giuffrè, 2005.

TROLLER, Alois. Von den Grundlagen des Zivilprozessualen Formalismus. Basel: Helbing, Lichtenhahn, 1945.

VOLLKOMMER, Max. Formenstrenge und prozessuale Billigkeit. München: Beck, 1973. 